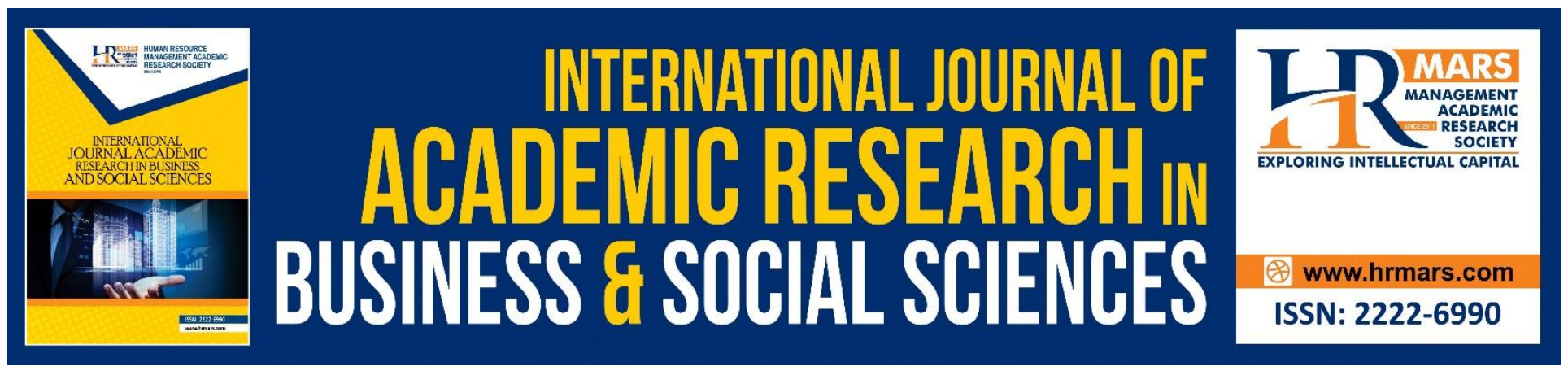

\title{
A Comparative Study of Government Policy in Dealing with Deviant Teachings in Islam: The Case of Malaysia and Turkey
}

Asmady Idris, Omer Kurtbag

To Link this Article: http://dx.doi.org/10.6007/IJARBSS/v9-i5/5872

DOI: $10.6007 /$ IJARBSS/v9-i5/5872

Received: 01 April 2019, Revised: 30 April 2019, Accepted: 01 May 2019

Published Online: 26 May 2019

In-Text Citation: (Idris \& Kurtbag, 2019)

To Cite this Article: Idris, A., \& Kurtbag, O. (2019). A Comparative Study of Government Policy in Dealing with Deviant Teachings in Islam: The Case of Malaysia and Turkey. International Journal of Academic Research Business and Social Sciences, 9(5), 305-324.

Copyright: (C) 2019 The Author(s)

Published by Human Resource Management Academic Research Society (www.hrmars.com)

This article is published under the Creative Commons Attribution (CC BY 4.0) license. Anyone may reproduce, distribute, translate and create derivative works of this article (for both commercial and non-commercial purposes), subject to full attribution to the original publication and authors. The full terms of this license may be seen

at: http://creativecommons.org/licences/by/4.0/legalcode

Vol. 9, No. 5, 2019, Pg. 305 - 324

http://hrmars.com/index.php/pages/detail/IJARBSS

JOURNAL HOMEPAGE

Full Terms \& Conditions of access and use can be found at http://hrmars.com/index.php/pages/detail/publication-ethics 


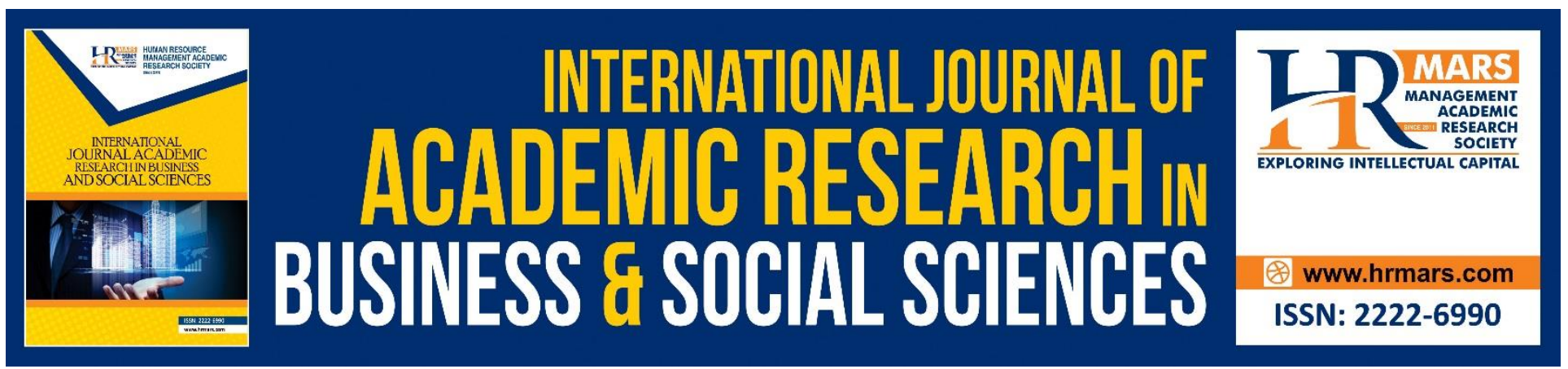

\title{
A Comparative Study of Government Policy in Dealing with Deviant Teachings in Islam: The Case of Malaysia and Turkey
}

\author{
Asmady ldris \\ Universiti Malaysia Sabah, Kota Kinabalu, Malaysia \\ Omer Kurtbag \\ Erciyes Universitesi, Kayseri, Turkey
}

\begin{abstract}
Since the collapse of the Ottoman Empire after World War I, Muslim wilayets (provinces) disintegrated and many were colonialized by the Allied powers comprising the Europeans, Soviet Union and the United States. Post-World War II, however, most of the Muslim wilayets started to achieve their independence and have become part of the modern state system. Muslim states were no longer paying their allegiance to the one single center of leadership as it was during the Islamic Caliphate era. The establishment of the Organization of Islamic Cooperation (OIC) in 1969 could not replace the Caliphate institution for it had no ultimate political power over Muslim countries. Every Muslim country now has their own religious practices. Undeniably, in managing religious affairs they have to deal with a lot of challenges. One of the challenges is the spread of deviant teachings which if no stern action is taken it may threaten the unity of the Muslim community. Meanwhile, Muslim countries have different policies and approaches in tackling the spread of deviant teachings. Therefore, the main aim of this study is to compare Malaysia and Turkey policies in dealing with the deviant teachings within their Muslim community, respectively. The comparative analysis will be revolved around the definition of deviant teachings, government policies and their implications in containing the spread of the deviant teachings in both countries.
\end{abstract}

Keywords: Islam, Deviant Teachings, Malaysia, Turkey, Comparative Study

Introduction

The phenomenon of deviant teachings in Islam is not new. It had occurred since the era of the Prophet Muhammad p.b.u.h and the Companions r.a. During these eras, the existence of deviant teachings was largely associated with the emergence of a few false prophets such as Musailamah Al-Kazzab, and Sajah Binti Al-Mundhir, and those who committed apostasy and spread deviant teachings among 
INTERNATIONAL JOURNAL OF ACADEMIC RESEARCH IN BUSINESS AND SOCIAL SCIENCES

Vol. 9, No. 5, May, 2019, E-ISSN: 2222-6990 @ 2019 HRMARS

their communities. All of them (except Tulaihah Ibn Khuwailid who returned to Islam), however, had been exterminated entirely during Saidina Abu Bakr and Saidina Umar al-Khattab r.a era. (Engku Alwi, 2015: 8-9; Ibn Hisham, 2013: 642-643; Sallabi, 2013: 305-307).

The assassination tragedy of the third Caliph, Uthman Ibn 'Affan r.a, and followed by the first two battles in the early Islamic era, the Battle of the Camel (656 AD) and more importantly, the Battle of Siffin (657 AD) between Saidina Ali r.a and Mua'wiyah r.a had split the Muslim community into three major factions; Saidina Ali r.a sect, which was later known as 'Syi' ah' (the supporters of Ali r.a), Mu'awiyah sect (founder of Umayyad Caliphate), and al-Khawarij sect which disapproved the Caliphate of Saidina Ali and Mu'awiyah r.a for both had committed 'big' sins. This scenario had simultaneously paved the way for the appearance of new teachings and approaches in understanding Islam as a religion.

Later, as Islam spread beyond the Arabian Peninsula, new ideologies and approaches in deliberating the nature of God and other metaphysical religious issues also appeared, such as Mu'tazilah, Murji'ah, Qadariyah, Jahmiyyah and others. These new groups of metaphysical ideologies, to some extent, caused bitter debate among Muslim scholars and the Caliphates. These groups, however, were overwhelmingly toned down with the birth of Al-Asya'irah and AlMaturidiyyah ideologies associated with the teachings of Imam Abu al-Hassan Al-Asy'ari (874-936 AD) and Imam Abu Mansur al-Maturidi (853-944 AD). Both Imams emphasized the importance of AlQur'an and Hadith as the primary sources of reference and also offered logical reasons to solve many heated issues related to the fundamental belief (Tawheed) in Islam. These Al-Asyai'rah and AlMaturidiyyah ideologies which later renowned as 'Ahlus Sunnah wal-Jama'ah' (ASWJ) or Sunni ideology, have become dominant in most of the Muslim countries nowadays. Even some countries like Malaysia has adopted it as the official religious doctrine (aqidah) for their Muslim community, while Turkey as the inheritor of the Ottoman Empire, Sunni ideology has been the religious backbone for her Muslim populace. In other words, the ASWJ doctrine becomes the basis of reference for both countries in identifying and differentiating any religious teachings that is considered as deviant vis-àvis the true fundamental belief in Islam.

For the purpose of this study which will focus on the Malaysia and Turkey policy in containing deviant teachings, the discussion will cover three main issues. Firstly, the study begins with the conceptual definition. Secondly, it examines the policy of Malaysia and Turkey to deal with the deviant teachings correspondingly, and thirdly, it analyzes comparatively both government's policies. The comparison analysis will deal with how Malaysia and Turkey define the deviant teachings, the attributes of deviant groups, and their institutional religious policies to contain the spread of the deviant teachings. The comparative approach on deviant teachings based on Malaysia and Turkey experiences could be considered as one of the new findings in studying Malaysia-Turkey relations, especially in the post-Ottoman era. It is also significant for many of the previous studies mainly focus on historical, diplomatic and socio-economic relations (Idris \& Kurtbag, 2013; 20; Ozay \& Saltik, 2015; Kurtbag \& Idris, 2018).

Added for Gap in literature review and significance of study 


\section{Conceptual Definitions of Deviant Teachings}

In examining the definition of 'deviant teaching', there are at least, two different perspectives which need to be considered. The first perspective is from a non-religious or secular world view. This perspective prefers to use the phrase of 'New Religious Movement' (NRM) rather than deviant religious teaching. The NRM phrase means to take a non-committal preference in defining or categorizing one religious ideology or practice over others. It avoids any attempt to classify or consider any religious ideology or practice as heretic or deviant. Furthermore, it also favors to define independently for every religious ideology of any negative character and simultaneously to recognize the differences between them. In other words, this perspective is freeing itself from being bound into any religious doctrines and it is more elastic by embracing the diversity of every beliefs and religious practices (Barker, 2013 \& 2014; Siegler, 2007).

The second perspective is from religious point of view. In fact, the term deviant or heresy is rooted from this perspective which obviously aims to differentiate between the 'truth' and 'deviant' in religious teachings. As had been concerned, all religions have undergone a headway process since their first appearance. In a few decades, largely due to ideological debates and to gain political influence, followers of a religion have been divided into several sects and groups and each of them claimed to be the real defender of their religion. They set the boundaries and whoever contradicted their teachings which may have been regarded as deviant and heretic. In short, deviant and heresy from a religious perspective could be viewed as a belief contradicting those of the group that is defining the heresy and the deviant teachings. Conversely, the heretics or the deviant sects did not see themselves as having false beliefs but rather as preserving or restoring a religious truth (Siegler, 2007: 25).

Concerned with the case study of this paper, it will use the second perspective, religious point of view, as to how Malaysia and Turkey define the deviant teachings for their Muslim audiences. The method of defining what is true and deviant in Islamic teachings for both countries ultimately belongs to their religious institutions respectively. This is how the policy is linked to the above connotation of what is 'deviant and heretic' from a religious perspective and is a belief which contradicts those of the group that is defining the heresy and the deviant teachings. 'Those of the group who are defining the heresy and the deviant teachings' here is indubitably referred to in the government policy of Malaysia and Turkey through their religious institutions like Islamic Development Department (JAKIM) and State Religious Council for Malaysia and Directorate of Religious Affairs (Diyanet) for Turkey. Both governments empower these institutions to look after the welfare of the Muslim community, including containing the spread of deviant teachings. This government religious institutional approach is in line with the Al-Quranic verse 59 Surah An-Nisa: "O ye who believe! Obey Allah, and obey the Messenger, and those charged with authority among you," which clearly obligates for every Muslims to obey Allah s.w.t, the Prophet p.b.u.h and Ulul Amri (those charged with authority among you). The meaning of the Quranic phrase "those charged with authority among you" can clearly be referred to the present ruling governments of Malaysia and Turkey. 
INTERNATIONAL JOURNAL OF ACADEMIC RESEARCH IN BUSINESS AND SOCIAL SCIENCES

Vol. 9, No. 5, May, 2019, E-ISSN: 2222-6990 ㄷ 2019 HRMARS

\section{Malaysia Government Policy on the Deviant Teachings}

After securing independence from Great Britain in 1957, Malaysia formed a Federation Government in 1963 and officially declared Islam as the religion for the Federation as mentioned in the Article 3(1). Despite this, the laws and the government structure is still similar to the British Political System where the role of religion is limited. Islamic religious laws and Shari'ah laws, are confined only in the Muslim personal matters, including marriage, inheritance, zakat (alms giving), financial-commercial issues etcetera. However, due to the rampant spread of deviant teachings among Muslim community in Malaysia, the government has taken various steps to contain these deviant teachings from harming the religious sanctity of Islam and political stability in this country.

From Malaysia's point of view, through the Department of Islamic Development Malaysia (JAKIM), deviant or heresy teachings are defined as 'any doctrines and practices initiated and supported by Muslims and non-Muslims who claim that the teachings are based on the teachings and practices of Islam whereas the teachings and practices contradict that of the Al-Qur'an and the Sunnah. They are also a contradiction to the Islamic faith and the venerated sects of the school of Ahl al-Sunnah wal Jama'ah' (AWSJ). Based on this definition, it vividly states that any teachings or practices that contradict Al-Qur'an, the Sunnah, and the school of Ahlus Sunnah wal Jama'ah or Sunni ideology will be considered as deviant or heretic teaching. Making the ASWJ doctrine as one of the ultimate references for all religious theological matters in this country is parallel with the National Fatwa 1996 (Engku Alwi, 2015; Mas'od, 2013).

A question may arise as to why Malaysia makes the Sunni ideology as one of the essential elements in identifying whether that particular teaching is deviant or not. To answer this question, the study may associate it with several features. Firstly, it is traditionally linked with the earliest Muslim preachers or traders that brought Islam in this region as early as the $7^{\text {th }}$ or $8^{\text {th }}$ centuries and who were found to be the followers of the Sunni theology and the Shafiite school (Arnold, 2012: 363369; Majul, 1964). Secondly, most of the writings of Sunni scholars have been used as the main theological textbooks for madrasah, and other religious schools in Malaysia since the $17^{\text {th }}$ century or even earlier. On top of that, ASWJ teachings promote moderation (wasatiyyah) and balance (mizan) vis-à-vis other theological sects such as Khawarij, Mu'tazilah, Jabariyah, Murji'ah, etcetera, which have so far served well the Malaysia Muslim community since independence (Mas'od, 2013).

In relation to the early development of the deviant teachings in Malaysia, it was generally believed that these teachings had come to this country as early as the $15^{\text {th }}$ century or earlier. They originated from the Middle East, Indo-Pakistan, and Indonesia (Ibrahim, 2003; Fadzil, 2011; Ismail, 2010). Customarily, common characteristics of the deviant teachings in Malaysia were mainly grounded upon Tasawwuf (Sufism) ideologies, especially Tasawwuf Wahdat al-Wujud, and Batiniyyah teachings which were rooted in the Abbasid era (Ibrahim, 2003). The earliest deviant teaching ever to appear in Malaysia was in 1872 in Penang known as 'Ajaran Taslim'. Later, the spread of deviant teachings continues to grow and up until today, there are about 125 or 127 deviant groups 
that have been identified, and currently active propagating their teachings (Engku Alwi, 2009; Mustafa, et al., 2013).

Today, the characteristics of deviant teachings can be categorized into three main attributes. The first type is related to the new forms of teaching. It is concerned with the old traditional beliefs such as Khawarij, Mu'tazilah, Jabariyah, Murji'ah, and others, and new modern secular ideologies that separate the religious affairs of life such as materialism, science, communism, socialism, capitalism, liberalism, and recent extremism-terrorism. The second type is largely linked to the tariqat - tasawwuf teachings. Most of the leaders of these groups are in camouflage in the forms of Tariqat movements like Tariqat Ahmadiyyah, Naqsyabandiyyah, Syadilliyyah, Qadiriyyah and others, in a manner which is inconsistent with the Islamic law. The third type is typically affiliated with traditional practices, superstitious beliefs, heterodoxy and polytheism. This deviance is believed to be influenced by other religions like Hinduism, Buddhism, animism and dynamism (Ibrahim, 2003; Engku Alwi, 2015).

In containing these deviant teachings, the Malaysia government has already issued fatwa (religious edict) on 55 teachings as deviant and heretical (Engku Alwi, 2015). The issuance of this fatwa is in parallel with the Federal Constitution. Article 11(4) which states that any efforts of spreading deviant teachings or heretical practices among Muslim community is strongly prohibited. The Federal Constitution also, in accordance with the Article 3(2), has put all matters related to the religion of Islam under the jurisdiction of all states in Malaysia. It constitutionally empowers every Ruler of the states as the Head of the Religion of Islam (except Malacca, Penang, Sabah and Sarawak which have no Rulers, the Yang Dipertuan Agong acts as the Head of Religion for these states) and the State Religious Council to formulate their own policies in preventing the spread of the deviant teachings (Federal Constitution, 2018: 28; Babulal \& Kannan, 2018).

All states in Malaysia have their own religious institutions called 'Majlis Agama Islam' (State Religious Council) to enact a fatwa on any religious issues. In regard to the deviant teachings, most of the State Religious Council share similar fatwas and policies as the teachings not only threaten one state but also other states in Malaysia. Hence, a concerted effort for all State Religious Councils is needed to curb a deviant teaching. The implementation of a fatwa and legal punishment has been placed under the State Syari'ah Criminal Enactment which will take action against a suspected deviant teaching group. The punishment includes the banning of the group, the detention of its leader and followers (jail sentences up to maximum of 5 years or fines up to RM3000 or both), and the rehabilitation program (Ismail, 2010). In analyzing how the government has tackled a number of deviant teachings, the study will focus on three deviant teachings which had been put on trial in the past. The three teachings were Al-Arqam, Ayah Pin and Tariqat Ahmadiyyah @ Qadiani.

\section{Religious Fatwa on Al-Arqam, Ayah Pin and Tariqat Ahmadiyyah @Qadiani}

\section{The Case of Al-Arqam}

Al-Arqam was one of the religious groups in Malaysia that was classified as deviant by the National Fatwa Council, 5th August 1994. This group was founded by Ashaari Muhammad in 1968 and its 
settlement base was in Sungai Penchala, Kuala Lumpur. Its followers were estimated at about 10,000 members. According to the National Fatwa Council there were 10 points of teachings of AlArqam that were found to contradict Islam, and it could be summarized into three major points.

The first point was the theological validity of Al-Arqam called 'Aurad Muhammadiah Pegangan Darul Arqam' (Aurad Muhammadiah, The Conviction of Darul Arqam). Al-Arqam believed that Aurad Muhammadiah's theology was directly taught by the deceased Prophet Muhammad p.b.u.h to Sheikh Muhammad Abdullah As-Suhaimi (a scholar of Arab-Javanese ancestry from Central Java) during a yaqazah (meeting in a state of consciousness and zauk or spiritual intoxication in spiritual form) in Mecca based on the writing of his grandson Mohd. Taha Suhaimi and approved by Ashaari Muhammad. The National Fatwa Council interrogated the validity of this claim, especially on the issue of yaqazah as it contradicted the majority of the Sunni Muslim scholars who firmly believed that the Prophet p.b.u.h can only be met in dreams and not directly. On top of that, Islamic teachings have been complete with Al-Qur'an and As-Sunnah which has looked after the purity of Islam after the passing of the Prophet Muhammad p.b.u.h until today (Abdul Hamid, 2005: 96-100; Abdul Hamid, 2013).

The second point was associated with the fundamental belief on the appearance of Imam AlMahdi as the Messiah at the end of this world to restore Islamic order and universal justice. Al-Arqam had a firm belief that the founder of Aurad Muhammadiah, Sheikh Muhammad Abdullah, would be the ideal person to become Imam Al-Mahdi to play the role as the waiting savior for all Muslims as mentioned in the Hadith related by Abu Dawud (4291): "Allah will raise, at the head of each century, such people for this Ummah as will revive its Religion for it". For he had the essential ingredients such as an ancestral lineage linking to the Prophet Muhammad p.b.u.h through his daughter Fatima r.a, a physical feature and a name 'Muhammad Abdullah' which accorded with the description of Al-Mahdi. This conviction was, however, refuted by the National Religious Fatwa especially on the issue of determining who Imam Al-Mahdi is and by associating with someone whom it was not yet certain, was the person who could be considered as Imam Al-Mahdi. Besides, the real name of the founder of Aurad Muhammadiah was not Muhammad Abdullah As-Suhaimi, instead his name was 'Muhammad Suhaimi Abdullah'. The third point was on the fanaticism of Al-Arqam followers for their leader as they seemed to create a personality cult, and a claim that a 'suicide army' in Thailand had been established (Abdul Hamid, 2005: 100-107).

Grounded upon these three major points, the leader, Al-Arqam and many of his followers were arrested and the group was banned. Ashaari Muhammad was detained in accordance with the Internal Security Act (ISA) which confined his movement only in the District of Gombak in Selangor from 1994 until 2002 before moving to Labuan, off the coast of Sabah, until 2004. While serving the sentence within the punishment area, they also need to undergo an Islamic rehabilitation process which was undertaken by the related religious agencies, and Ashaari Muhammad himself was required to present a report on his activities to the nearest police station once a week Ibid: 88 ; ). After serving the sentence of 10 years, Ashaari Muhammad was released on 25 October 2004 under 
the new premiership of Datuk Seri Abdullah Badawi (Malaysiakini, 2004), nonetheless, the banning of Al-Arqam remained unchanged. The leader of this movement finally died on 13 May 2010 and his body was buried in his Kampung Pilin, Rembau Negeri Sembilan (Malaysiakini, 2010).

\section{The Case of Ayah Pin}

The Ayah Pin teaching was directly linked to the founder of this group named Arifin Muhamad also referred as 'Ayah Pin'. He considered himself as the representative of God and his followers believed that he received divine revelations from heaven. The main doctrine of this group was called 'Kumpulan Ratib Kuat Ayah Pin', and it operated in Ayah Pin's 'Sky Kingdom' which was built in Besut, Terengganu, one of the states on the east coast of Malaysia. The Sky Kingdom which resembled the Disney World style had attracted a lot of followers (Ishak, 2016; David, 2016, Ariffin, 2016).

Among his teachings, Ayah Pin believed that he had direct contact with the heavens, and to be the reincarnation of Jesus, Buddha, Shiva and the Prophet Mohammad p.b.u.h. He also claimed to be able to make himself invisible, and to be rewarded with the aptitude to kill a man using the power of thought. His cult had no moral or religious teachings of its own, instead he claimed that members could follow any religion they chose and be sure that their prayers would be answered, because "I am representing the ministers of the Sky Kingdom, to unite humankind, regardless of race or religion." (David, 2016).

In conjunction with the above teachings, Ayah Pin and his teachings were declared deviant by the Terengganu Religious Council and Malay Custom in 1985 and legally issued a Fatwa in 1997 to ban him and his followers from performing their religious activities. Moreover, due to Ayah Pin's actions of renouncing Islam in 2001, he was imprisoned for 11 months and fined RM2,900. Despite his arrest, his Sky Kingdom continued to operations and recruited new followers among university students and indigenous people. In 2005, Ayah Pin's Sky Kingdom was demolished and 48 of his followers were arrested. Nevertheless, Ayah Pin escaped from this onslaught and went over the border of Thailand. On April 22, 2016, Ayah Pin died in his hometown Kampung Batu 13, Hulu Besut, Terengganu (Ismail, 2010; Ishak, 2016; David, 2016).

\section{The Case of Tariqat Ahmadiyyah @ Qadiani}

The third case study of the Malaysia deviant teaching is Tariqat Ahmadiyyah @ Qadiani. As had been known, this group which based on tariqat or spiritual learning, was founded by Mirza Ghulam Ahmad Qadiani in India in 1885. It began to arrive in Malaysia in the1930s in Batu 20 Jeram, Kuala Selangor, and spread into other places including Kampung Nakhoda, Batu Caves, Serdang in Selangor, Kota Kinabalu and Sandakan in Sabah, Jasin in Melaka, and Kedah. The main teachings of this group were intently associated with the founder's claims as a prophet, Imam Al-Mahdi, Isa Al-Masih, possession of miraculous power (Mu'jizat), and others (Mustafa et al, 2013: 26-27; Engku Alwi, 2015). 
This group was declared as deviant on 18 June 1975, and its followers were no longer considered as Muslims which indirectly obstructed them to claim any rights to Muslim communities in Malaysia. The Ahmadiyyah group mounted a challenge in the Shah Alam High Court on 6th July 2018, against the Selangor Religious Council's fatwa of 2014 which prevented them from performing Friday Prayers at a shop lot house in Batu Caves. The outcome of the challenge was that the group could freely practice their activities for they were no longer considered Muslims and their rights were guaranteed by the Federal Constitution Article 11 on the freedom of religion. Nevertheless, this group is not allowed to convey their teachings to Muslims. For it would be considered as a violation of the rights of Islam and Muslims as enshrined in the Article 11(4) of the Federal Constitution (Nambiar, 2018; Alhadjri, 2018; Babulal \& Kannan, 2018)

\section{Turkish Government Policy on the Deviant Teachings}

During the republican era, the young Turkish republic under Kemal Atatürk was designated constitutionally as a secular state and the role religion would play was limited to only the private sphere, thereby dismissing religion from the public sphere. Thus, as part of a set of modernization reforms, certain laws of Kemalist era put a strict ban on Sufi orders, lodges and shrines. Despite this, Turkey established constitutionally a Presidency of Religious Affairs (Diyanet İşleri Başkanlığı) whose mandate was to govern religious matters officially. "It was believed that if religious affairs were left entirely in the hands of communal organizations, Islam would inevitably retain its hold over Turkish society, its laws, politics, economics" (Özbudun, 2011, p. 27). In other words, apart from the Diyanet, all non-state-run religious organizations were declared legally null and void (Jassal and Akçapar, 2017).

Despite the preventative and drastic legal measures and sweeping reforms, the following governments in the post-Atatürk era tended to ignore the restrictions imposed by the laws as the legacy of Kemalism in this respect has gradually lost ground. Apparently, these sects, orders and lodges have not vanished at all, on the contrary, they have existed as a "de facto and social reality" since the early days of the Republic. Religious-looking groups took advantage of the legal void and hence, in the end there emerged an unsupervised area of influence, sometimes badly exploited by these groups. After having remained inefficient and dysfunctional until the 1950s, the Diyanet sought to promote the belief and principles of Sunni Islam, respond to the needs of public concerning religious problems, and administer thousands of mosques across Turkey. However, it had no legal authority over these types of groups and their deviant activities. With the arrival of the conservative Justice and Development Party in 2002, the influence of religion has become increasingly more prominent in public life and political discourse while the Diyanet still remained silent and inactive on the sensitive issue of deviant teachings and communal organizations. Ataman (2017: 10) argues here that "When the Justice and Development Party (AK Party) came to power in 2002, it promised to normalize the country by initiating a process of democratization, demilitarization and civilianization. The AK Party government took significant steps in this regard which allowed the arena of civil society to expand and increased diversity in social and political life." During this process of political democratization under the JDP (Justice and Development Party) government, the religious orders and lodges were considered civil society organizations by both liberals and political Islamists who 
believed that the legitimatization of their places in the public sphere was a substantial gain for Turkish democracy and pluralism (Demir, 2018). In this climate, these organizations felt increasingly free to influence and shape the politics as well as social order in their own image. Some of them even sought to abuse this freedom to maneuver and therefore these abuses sparked a heated debate as to whether the sects and religious communities should be kept under control or not, as will be analyzed below.

\section{Turkey's Dealings with Deviant Teachings and Groups}

In recent times, deviant discourses and activities that seek to deceive the public religiously and thus have a disruptive effect on the public order have been on the rise in Turkey. In order to counter them, several deviant teachings and groups are specifically targeted by both the Diyanet, which launched a widespread campaign in an attempt to fight deviant teachings and groups, and the Turkish government, which sees these deviant teachings and groups a major threat to peaceful societal order and political stability in the country.

In January 2017, under then head of the Diyanet, Mehmet Görmez, the Presidency launched a pioneering initiative that brought around 30 leading religious groups together under its guidance, to a meeting and resulted in the declaration of five principles that should be obeyed by these organizations. In Görmez's words, "First of all, they should never be involved in violence. No matter who he is, if a person or a group applies violence, he has to face all of us as a nation. Secondly, it should never declare someone or some group as a nonbeliever. Third, never marginalize. Fourth, it should never leave the main frame of Islam or in other words knowledge. Fifth is the putting human kind to the center. Realities should not be replaced by persons. Eternal truth cannot be built around mortal personalities." (Important Remarks, 2016) This initiative and the emerging principles in the end were the first of their kind in the history of the Diyanet. Against this background, after emphasizing that religious sects have spread Islamic knowledge, teachings and wisdom throughout the history of Islam, the existing President of Religious Affairs, Professor Ali Erbaş, warned first that "A control and guidance mechanism should be established that will not overshadow the civilian structure of the religion or impair the liberties, and ensure the safety of religion." Secondly, he underlined that "the work or legal arrangements in this area should be done in a way that will not adversely affect the structures carrying out useful practices with authentic religious knowledge and sincere efforts, and rather, guide them properly." Under Erbaş, the Diyanet launched a campaign across Turkey in order to cope with the exploitation of religion by these deviant groups and was obviously critical of any understanding of a sect or order which was truly Islamic and others not. It thus stressed that if it does not contradict the principles and rules of Islam, any group cannot be considered deviant or harmful to the social order. According to Erbaş, "The Government and the Presidency of Religious Affairs should take on the guidance role and come together with experts in order to establish a discipline and order. Otherwise, the exploitation of religion comes around..." In analyzing how the Diyanet and Turkish government took action against some of the deviant groups, the study will focus on four groups, named the Gülenism, DAESH, Adnan Oktar and Iskender Evrenesoğlu Groups. 


\section{The Case Study of the Gülenism}

In the aftermath of the $15^{\text {th }}$ July 2016 coup attempt perpetrated by the Gülenist cabal within the Turkish military, the Diyanet eventually played an important role in countering the FETO threat by informing Turkish people regarding the deviant teachings as well as abuses and misdeeds of Islam by these kinds of groups. To illustrate, the Diyanet's report titled "Kendi Dilinden FETÖ: Örgütlü bir Din İstismarı" suggests that Gülen's views about himself, his community and followers, and other Islamic communities are apparently deviant in the sense that he claims to represent the true face of Islam by disparaging other groups, declaring his followers the most sacred (golden) generation of Islam and is involved in developing an inter-faith dialogue with other religions at the expense of Islam. (Kendi Dilinden FETÖ, 2017). On $15^{\text {th }}$ July 2018, the second anniversary of the coup attempt, in reference to the Gülenism, Professor Ali Erbaş, the existing President of Religious Affairs, said, "It is a movement of deviance in creed, practice and morality that distorts and destroys all the values of Islam and uses them for its dark and despicable purposes... From this point of view, I have to express that we have to be more careful altogether against those who abuse and exploit our religion for their own purposes, and aim at our religion, union, solidarity, peace and brotherhood." (PRA, 2018) As a result, the Diyanet enhanced its anti-deviant posture by participating in the $15^{\text {th }}$ July Day of Democracy and National Unity, holding Mawlid programs for martyrs of the July $15^{\text {th }}$, preparing a short documentary for the second anniversary of the coup attempt, and publishing and disseminating books and booklets titled "FETO - An Organized Exploitation of Religion", "The Gülen Organization", "the Road to July 15: Analysis of FETO and Recommendations", "FETO: Terrorist Organization Concealing Behind the Religious Abuse".

This sharp position also attracted some foreign religious authorities such as the Council of Ulema Tariqas of Indonesia/ASEAN, who shares the almost identical views about FETO as the Diyanet. According to the Council's recent fatwa issued on 5th October 2018, all FETO activities are deemed Haram and should be forbidden. The text of the fatwa is as follow: (Daily Sabah, 2018)

"1. Fetullah Gülen has deviated a lot in interpreting the verses of the Qur'an, and his teachings and thoughts can damage the Islamic Aqedah based on the Qur'an and the Sunnah of the Prophet Muhammad p.b.u.h;

2. Early in spreading his teachings, Fetullah Gülen taught in the name of Bediuzzaman Said Nursi, but after investigation in the past few years, he turned out to have deviated from Bediuzzaman Said Nursi's teachings. Bediuzzaman Said Nursi was only used to attract the sympathy of Muslims, especially among the youth and campus activists;

3. Fetullah Gülen with all his actions and thoughts on Islam, especially about Sufis, is a heretic who will damage the Sufi values themselves; and

4. Movement or the Fetullah Gülen group that is currently developing is not just a movement or a socio-religious organization but a movement or organization that is more directed to the form of 
INTERNATIONAL JOURNAL OF ACADEMIC RESEARCH IN BUSINESS AND SOCIAL SCIENCES

Vol. 9, No. 5, May, 2019, E-ISSN: 2222-6990 @ 2019 HRMARS

terrorist organizations that hide behind a mask of social and religious movements that have a closeness to Zionists."

The fatwa thus encourages both Indonesian and other states' public authorities to unite against all forms of FETO activities in their respective countries. Followers of Gülen also are called by the Council "to repent to Allah and account for their actions towards Muslims in the world, especially what has happened in Turkey on July 15th, 2016.

As for government-led measures, the most threatening deviant group is the reclusive Fetullah Gülen's organization based in the US. The Gülen group was being held responsible by the Turkish government, for masterminding and perpetrating the failed coup attempt in Turkey on 15th July, 2016 which sought to overthrow the Erdoğan rule in Turkey. While his organization "identifies itself as an Islam-inspired civic, cultural and education movement," it was already declared a terrorist organization (FETO-Fetullahist Terrorist Organisation) by the Turkish authorities in May 2016, nearly two months before the coup attempt (Aktürk, 2017). Despite this, US government reports still identify Fetullah Gülen as "a self-exiled Islamic cleric" and his group as a "movement" rather than a criminal organization (Country Reports on Terrorism, 2017, p. 116) or "a chimera hidden behind the façade of religious discourses" (Ataman, 2017, p. 12).

The posture of the Western media towards the $15^{\text {th }}$ July coup attempt was indeed questionable as they heavily distorted the reality by picturing the events as if there were two legitimate forces in conflict (Ataman and Shkurti, 2017). Thus they did not hesitated to portray the putsch as a struggle between President Erdoğan and his political opponents, and the US-based NBC news channel falsely reported that Erdoğan had sought asylum from Germany (Ataman and Shkurti, 2017). In addition, even after the defeat of the coup attempt by the Turkish armed forces and the civilians, the Western news channels insisted that the identities of the coup plotters were not able to be clearly identified; they were badly tortured by the resisting anti-coup civilians, and lastly, "cleric" Gülen and his group would not be behind such an evil act (Ataman, 2017). One example is Sloat's definition of Gülen: "An Islamic cleric and scholar, Gülen is seen as the spiritual leader of a transnational religious movement known as "Hizmet" (translated from Turkish as "service")" (Sloat, 2018: 2). According to a Turkish political scientist, nevertheless, given the literature over these sort of groups, it is possible to describe this secretive group as a closed and cult-like sect led by Gülen as an invincible guru who sees himself as "Mahdi", the savior of mankind (Yayla, 2017). Therefore, the Gülenists' post-coup campaign against Turkey and President Erdoğan was easily and unquestionably acknowledged by the Western media and think tanks as this picture only enhanced the perception of Turkish public opinion that the West was discontent with the failure of the coup attempt (Aktürk, 2017).

In the aftermath of the putsch, the Turkish police investigated more than 100.000 individuals for their alleged links with this network and most of them were either dismissed or suspended. Given the powerful and shadowy "state within state" established by the Gülenists (Aktürk, 2017), these included public officials, teachers, soldiers, police officers and even Diyanet employees (Filkins, 2016; 
Report 2017, p. 7). President Erdoğan was openly critical of the inefficiency and delayed response of the Diyanet in recognizing and dealing with the deviant groups such as FETO, thereby leading to the immediate resignation of the president of the Diyanet, Mehmet Görmez. With reference to FETO and its infiltration into the state institutions for nearly four decades, Görmez emphasized in his last speech as the head of the institution that "the Diyanet should never be ashamed of being 40 years late again regarding a deviant religious organization." (Gürgür, 2017) This was an outspoken self-criticism on the part of the Diyanet as it was not able to preempt the deviant character of the group in advance. Another former president of the Diyanet, Ali Bardakoğlu, also acknowledged that the Diyanet has long remained silent as the deviant teachings and groups have been ascendant and it arguably hesitated over whether to warn the public about their harmful activities (Gürgür, 2017). In the postcoup period, Turkish public opinion towards Gülen and his group has become increasingly hostile since it was widely believed that he would establish an authoritarian rule or a dictatorship based on his deviant understanding of Islam should the putsch be successful (Miş, 2017).

\section{The Case Study of DAESH (Islamic State of Iraq and Shams, ISIS)}

In addition to FETO, the Diyanet's posture toward the exploitation of Islam by the deviant DAESH terror network has become increasingly tougher. It has taken a key initiative by disclosing the true and violent face of this terrorist organization by both publishing scholarly works over its distortion of Islamic principles and by condemning the extremely violent acts it committed. In an apparent awareness-raising effort, the Diyanet's recent report, titled "Exploitation of Religion and Terrorist Organization DAESH" published in late 2017, made a strong case that DAESH's roots can be found in the alienation of migrant and minority Muslim youth living in the West who face discrimination in public domain and easily fell into the trap of these violent extreme groups. DAESH's abuse of religion can be observed in its decontextualization and misinterpretation of hadith and verses in order to legitimize its religious discourse. Therefore, it represents "the Islamization of radicalism" since its exclusionist interpretation of Islam is devoid of a healthy religious approach in the absence of no scholarly capacity on the part of its adherents and leadership. This eclectic and literalist misinterpretation of Islam and its main concepts such as jihad is grounded on an exploited salafiWahhabi perspective that defends a return to pure understanding of Islam prevalent in the early period. One of the most dangerous tools DAESH has used in marginalizing Muslims is takfir. The report finds that "DAESH practices the act of takfir on any group and their members which they consider to be political enemies, especially groups that are against them." This misuse of takfir for political intentions is of course not in line with Ahl al-Sunnah's mainstream interpretation of who can be considered a disbeliever and under what conditions. From DAESH's perspective, for instance, Muslims of Turkey including the heads of government can be regarded disbelievers and so they are required to repent. Finally, DAESH's claim of becoming the only true representation of Islam is related to the issue of a caliphate. DAESH leader al-Baghdadi is viewed by the DAESH militants as the caliph of the so-called Islamic State they sought to establish, which is again neither valid nor binding in religious terms at all in the view of the Ummah since it does not meet the conditions of the doctrine. Therefore, "Practices of DAESH with the claim of being the Islamic state have brought damage on many individuals and groups particularly the religion of Islam itself and Muslims." (Exploitation of Religion..., 2017) 
As far as the Turkish government's measures to combat DAESH terrorism are concerned, Turkey declared it as a terrorist organization which posed a direct threat to Turkish security interests near and beyond Syrian border (Schanzer and Tahiroglu 2014, p. 17). According to the highly-biased Western narrative, Turkey was unable to halt illegal border crossings, weapons smuggling and medical treatment of DAESH terrorists in some Turkish hospitals (Bipartisan Policy Center 2015, pp. 11-14). In response, however, Turkey took many domestic measures against DAESH such as strengthening border security, further intelligence sharing with origin countries and intensifying border patrols and air surveillance. (Yeşiltaş 2015, pp. 14-31). Also Turkey opened Incirlik air base to US-led anti-DAESH coalition forces in July 2015 (Kibaroglu and Sazak 2015, pp. 98-99). Its participation in the coalition air strikes against DAESH nevertheless led to further vulnerability to DAESH attacks like the fatal one that targeted Istanbul Atatürk Airport in June 2016 (Dalay 2016). Despite this, Turkish security forces did not stop carrying out preventive operations against suspected DAESH elements in Istanbul and other cities and thus the number of DAESH recruitments have declined. A Turkish military incursion, codenamed Operation Euphrates Shield, and started in August 2016, with the aim of destroying threatening DAESH military presence in northern Syria, was conclusive indeed. (Seren 2017).

\section{The Case Study of Adnan Oktar and Iskender Evrenesoğlu Groups}

Other controversial and mysterious religious groups probed by the Turkish authorities are marginal televangelist Adnan Oktar's and Iskender Evrenesoğlu's. In the view of the Diyanet, Oktar's group was a criminal network, which like FETO, exploited a legal void and "deceived many, especially young people, who are religiously highly sensible but unlearned, and transformed them into militants working for the interests of the hidden, dirty and dark power groups, against their own state and nation, and wasted many of our young men and women and darkened their futures" (A Control and Guidance, 2018) In January 2018, too, the Diyanet reported by referring to Aktar that "he has most likely lost his mental balance" in response to his heavy distortion and abuse of Islam (BBC, 2018). On the morning of July 11,2018 , his compound in Istanbul was raided by the Turkish financial crime police and he was arrested alongside more than 160 people who had been linked with his group during the operation, across five provinces. Among the charges directed towards him and his followers were sex abuse, fraud, tax offences, kidnapping and sexual intercourse with minors. Hundreds of young men and women were recruited by Adnan Oktar into his cult-like group during the 1990s. His understanding of Islam was deviant in the sense that he seeks to challenge Darwin's theory of evolution with his books published under the pen name of "Harun Yahya" while his televised sermons were hardly in line with Islamic rulings, most notably dress code, as scantily-clad young woman singing and dancing around him very bizarrely (CNN, 2018).

As for US-based marginal "cleric" Evrenesoğlu, who has declared himself as both "Mahdi" and "prophet", the Diyanet are currently taking steps to deal with his deviant ideas and publications. "Evrenesoğlu had claimed that he received a revelation as a prophet of Allah, which he compiled into a book "The Lights of Prophecy." (Hurriyet Daily News, 2019) Upon the Diyanet's complaint over these revelations, a Turkish court in late January 2019 put an access ban on five web sites spreading this self-proclaimed false prophet's deviant views and commentaries which are in violation of basic 
Islamic principles and rules (Trthaber, 2019). These marginal typologies and false prophets, as one analyst argued, "define themselves as spiritual authority for the salvation of mankind, regard their subjective experiences as a source of religion in the transmission of religious knowledge... Despite hundreds having been in the same allegation throughout history, none brought any peace, yet they themselves were the cause of trouble." (Akın, 2018, p. 66)

\section{Comparative Analysis}

The comparative analysis of this study will revolve around three points: the conceptual definition of deviant teachings, the attributes of deviant groups, and institutional religious policies to contain the spread of the deviant teachings. With regard to how the religious institutions define a deviant teaching, it is solely based on the structural nature of both governments. For Malaysia which is a Federal Constitutional Monarchy and Islam is the federal religion, it empowers every states to govern Islamic affairs without intervention from the Federal Government. Nevertheless, any laws passed by states should not contradict the Federal Constitution. Thus, in matters related to the definition of deviant teachings, it was formulated according to the National Fatwa of 1996 (every states officially affiliated with this fatwa) which legally accepted the Ahlus Sunnah wal Jama'ah as the ultimate reference for any religious matters in Malaysia. Any religious teachings or groups found to be incongruent with Al-Qur'an, As-Sunnah and the practice of Sunni ideology will be declared as deviant.

When it comes to Turkey, it is a Parliamentary Republic, designated as constitutionally secular since its foundation. No state religion exist in Turkey constitutionally. There is The Diyanet, a central government institution governing religious issues and problems; there is no reference to any religion or sect in the Turkish Constitution. In practice, however, the Diyanet seeks to promote the belief and the principles of Sunni Islam in responding to the needs of the public concerning religious problems.

In terms of the attributes of the deviant groups in Malaysia and Turkey, some similarities could be found. For instance, most of the philosophical teaching of the groups was heavily centered upon the issue of the coming of Imam Al-Mahdi as the future savior for Muslims. The use of the resemblance of the personality of Imam Al-Mahdi as foretold was inculcated in their leaders to be personified as a devoted person so that it might enhance the group reputation, particularly in recruiting new followers. In addition to that, the deviant groups in both countries are potentially threatening the security and the stability which directly prompted the governments of Malaysia and Turkey to take harsh action to thwart such operations. Apart from the similarities, there are differences in the characters of the deviant groups where most of the deviant groups in Malaysia are locally oriented, although some are received from external influences, and this has not unduly affected Malaysia's relations with other countries. In Turkey, the outlook is strikingly different. This is because the deviant teachings and groups facing Turkey are mostly international in character (foreign-driven) or their activities are transnational as in the case of Gülen's dark network. This picture has severely affected bilateral relations of Turkey with other countries, most notably the US and the European countries which either regard these groups as merely civil society organisations and even host them. 
In dealing with the deviant teachings and groups, both governments have their own religious institutions to look after this issue. For Malaysia, the State Religious Councils and JAKIM may work together to issue a fatwa on banning any group that is claimed to spread these teachings. As a unitary state, nonetheless, Turkey has a more centralized system in its dealings with such groups. Indeed, the Diyanet unofficially supervises the compliance of religious communities with some principles they are supposed to obey. Currently there is also a search for an official and permanent mechanism regulating and disciplining these organizations. Also Turkey still needs an official domestic containment mechanism strategy. In this regard, when compared to Turkey which has been quite late in containing these teachings and groups, Malaysia seems to have a more decentralized, established and efficient system.

In terms of legal punishment inflicted upon these teachings and their believers, Malaysia appears again ahead of Turkey by first introducing legal codes and then passing sentences such as jail sentences with a maximum term of up to 5 years or fines up to RM3000 or both as well as a rehabilitation program for deviant group followers in Da'wah Rehabilitation Centers. In comparison to the Malaysian system, Turkey has neither similar legal codes or punishment systems nor any rehabilitation program or institution. Until now, Turkish courts concluded mass trials which resulted in purges of thousands of deviant group followers from public institutions as well as the takeover of businesses belonging to them by the state authorities, while police operations at home and military incursions abroad have been conducted. Thus Turkey had to take more sporadic but severe legal measures and impose harsher punishments when compared to Malaysia since the deviant group followers or their affiliates have had a much deeper influence on the Turkish state and civil society institutions

\section{Conclusion}

Deviant teachings and groups, which have always been existent in the history of Islam, are ascendant across the Islamic world. Despite that they are the two distant Muslim-majority countries, both Malaysia and Turkey have recently faced the same threat emanating from these teachings and groups. In countering this threat, both country's government's approaches share some similarities but at the same time, various differences. Based on the Islamic religious scholarship and institutions on the Sunni sect of Islam either officially (as in case of Malaysia) or unofficially (as in case of Turkey), their top religious authorities are in charge of this struggle with the deviant understandings of Islam. In this regard, Malaysia seems to have an earlier recognition of the extent and scope of this threat and thus set up more established and effective scholarly and institutional capacities. On the contrary, Turkey's Diyanet, which have had no legal authority over the religious communities including the deviant ones, seems to have delayed recognizing them but it has been more active and aggressive recently in countering the threat such groups pose. Turkey also needs a comprehensive and effective disciplinary or controlling body or authority over these groups. Its lack of any rehabilitation program or institution for the followers and victims of deviant groups is also noteworthy when compared to Malaysia's case which has both elements and has implemented an efficient policy in containing the spread of harmful activities by these deviant groups. 
INTERNATIONAL JOURNAL OF ACADEMIC RESEARCH IN BUSINESS AND SOCIAL SCIENCES

Vol. 9, No. 5, May, 2019, E-ISSN: 2222-6990 @ 2019 HRMARS

\section{References}

Abu-Hussin, M. F., \& Salleh, M. A. (2016). Saudi Arabian - Malaysian Relations. In N. Partrick (Ed.), Saudi Arabian Foreign Policy (pp. 290 - 303). London, UK: I.B.Tauris

Abu-Hussin, M. F., Idris, A., \& Salleh, M. A. (2018). Malaysia's Relations with Saudi Arabia and Iran: Juggling the Interests. Contemporary Review of the Middle East, 5 (1), 46-64. doi:10.1177/2347798917744294. Available at https://doi.org/10.1177/2347798917744294.

Alatas, S. F. (2014). Salafism and the Persecution of Shi'ites in Malaysia. Retrieved from http://www.mei.edu/content/map/salafism-and-persecution-shi\%E2\%80\%98ites- malaysia.

Majlis-e-Ulama-e-Shia-Europe. (2013). Mahathir Mohamad: Shia Teachings Should Not Be Practised In Malaysia. Retrieved from https://majlis.org.uk/mahathir-mohamad-shiaTeachings-should-not-be-practised-in-malaysia/. Date of accessed: 3 October 2017.

Adnan Oktar: Turkish TV Preacher Arrested on Fraud and Abuse Charges. (2018, July 11).

$B B C$, July 11, 2018, retrieved from https://www.bbc.com/news/world-europe-44792102. Date of accessed: 27 November 2018.

Akın, M. (2018). Günümüzde Bazı Marjinal Mehdî Tiplemeleri ve Söylem Analizleri. Kader, 15 (1), p. 66-88.

Aktürk, Ş. (2017). Turkey's Civil Rights Movement and The Reactionary Coup: Segregation, Emancipation, and the Western Reaction. In Muhittin Ataman (Ed.), July 15 Coup Attempt in Turkey: Context, Causes and Consequences. Ankara: SETA.

Alhadjri, A. (2018). Tangis Syukur Pengikut Ahmadiyah di Mahkamah, Malaysiakini, 6 Julai, Retrieved from: https://www.malaysiakini.com/news/433041. Date of accessed: 2 December 2018.

Ariffin, M. (2016). Cult Leader - Obituary. The Telegraph, 5 May, Retrieved from: https://www.telegraph.co.uk/obituaries/2016/05/05/ariffin-mohammed-cult-leader-obituary/_Date of accessed: 3 December 2018.

Arnold, T. (2012). The Spread of Islam: A History of Peaceful Preaching. New Delhi: Goodword Books.

Ataman, M. (2017). Introduction. In Muhittin Ataman (Ed.), July 15 Coup Attempt in Turkey: Context, Causes and Consequences. Ankara: SETA.

Aydın, B. (2003). Meclis-i Meşâyih. Türkiye Diyanet Vakfı İslam Ansiklopedisi, 28.

Babulal, V., \& Kannan, H. K. (2018). Mujahid: Guidelines Needed to Differentiate Between Syiah Followers, Promoters. New Straits Times. Retrieved from: https://www.nst.com.my/news/nation/2018/11/433004/mujahid-guidelines-neededdifferentiate-between-syiah-followers-promoters. Date of accessed: 10 December 2018.

Barker, E. (2013). New Religious Movements: Their Incidence and Significance. In Bryan Wilson. (ed). New Religious Movements: Challenge and Response. July 19, 2018. Barker, E. (2014). The not-so-new Religious Movements: Changes in 'The Cult Scene' Over the Past Forty Years. The Finnish Society for the Study of Religion. Temenos. 50 (2), 235-256. Country Reports on Terrorism 2017. (2018, September). US Department of State, Retrieved from: https://www.state.gov/documents/organization/283100.pdf. Date of accessed: 30 November 2018. 
INTERNATIONAL JOURNAL OF ACADEMIC RESEARCH IN BUSINESS AND SOCIAL SCIENCES Vol. 9, No. 5, May, 2019, E-ISSN: 2222-6990 @ 2019 HRMARS

Controversial Turkish Televangelist Arrested. (2018, July 11). CNN, Retrieved from: https://edition.cnn.com/2018/07/11/europe/turkey-televangelist-arrested-intl/index.html. Date of accessed: 30 November 2018.

David, A. (2016). Ayah Pin, "Sky kingdom" Sect Leader is Dead, New Straits Times, 23

April, Retrieved from: https://www.nst.com.my/news/2016/04/140972/ayah-pin-sky-kingdomsect-leader-dead. Date of accessed: 3 December 2018.

Demir, H. (2018, July 27). Türkiye'nin Cemaatlerle İmtihanı. Türkiye, Retreived from: http://www.turkiyegazetesi.com.tr/yazarlar/hilmi-demir/603396.aspx. Date of accessed: 4 December 2018.

Engku Alwi, E. A. Z. (2010). Ajaran Sesat di Malaysia. Jurnal Peradaban, 3, 1-16,

Engku Alwi, E. A. Z. (2015). Ajaran Sesat di Malaysia: Faktor Penyebaran dan Cara Penyelesaiannya. Kuala Lumpur: Dewan Bahasa \& Pustaka.

Exploitation of Religion and Terrorist Organization DAESH. (2017). The Presidency of Religious Affairs, Ankara, Retrieved from: https://dosya.diyanet.gov.tr/DIYKDosya/YayinDosya/94342976-b84f-495c-b7bcd8a32498d6a4.pdf. Date of accessed: 4 December 2018.

Fadzil, A. (2011). Deviant Teachings in Malaysia and Theirs Interpretation of the Qur'an. International Journal of Humanities and Social Sciences. 1, 20, 183-194, Retrieved from: http://www.ijhssnet.com/journals/Vol_1_No_20_December_2011/18.pdf. Date of accessed: 12 November 2018.

Federal Constitution. (2018). Petaling Jaya, Selangor: International Law Book Services.

Filkins, D. Turkey's Thirty-Year Coup. (2016, October 17). The New Yorker, Retrieved from: https://www.newyorker.com/magazine/2016/10/17/turkeys-thirty-year-coup. Date of accessed: 5 December 2018.

Gürgür, N. (2017, August 24). Çözümü Zor Bir Sorunlar Yumağı: Diyanet İşleri Başkanlığı-

Dini Cemaatler, Tarikatlar, Gruplar. Türk Ocakları. Retrieved from: https://www.turkocaklari.org.tr/yazar/nuri-gurgur/cozumu-zor-bir-sorunlar-yumagi-diyanetisleri-baskanligi-dini-cemaatler-tarikatlar-gruplar-8091. Date of accessed: 30 November 2018.

Hamid, A. F. A. (2005). The Banning of Darul Arqam in Malaysia. Review of Indonesian and Malaysian Affairs. 39(1): 87-128, retrieved from: https://www.academia.edu/331972/The_Banning_of_Darul_Arqam_in_Malaysia. Date of accessed: 30 November 2018.

Ibn Hisham, 'A. Al. M. (2013). The Prophetic Biography: Sirah of Ibn Hisham Trans. By Dr. Muhammad Mahdi Al-Sharif. Lebanon: Dar Al-Kotob Al-Ilmiyah.

Ibrahim, A. H. (2003). Ajaran Sesat. Kuala Lumpur: Dewan Bahasa \& Pustaka.

Idris, A. \& Kurtbag, O. (2013). Malaysia-Turkey Relations in History and Today.

Middle East Asia Project. Middle East Institution, November 19, Retrieved from: https://www.mei.edu/publications/malaysia-turkey-relations-history-and-today. Date of accessed: 7 November 2018. 
INTERNATIONAL JOURNAL OF ACADEMIC RESEARCH IN BUSINESS AND SOCIAL SCIENCES Vol. 9, No. 5, May, 2019, E-ISSN: 2222-6990 @ 2019 HRMARS

Important Remarks from President of Diyanet Görmez. (2016). The Presidency of Religious Affairs, Retrieved from: https://www.diyanet.gov.tr/enUS/Institutional/Detail/9946/important-remarks-from-president-of-diyanet-gormez. Date of accessed: 8 November 2018.

Ishak, M. (2016). Ayah Pin Meninggal Dunia Malam Tadi, Berita Harian, 23 April, https://www.bharian.com.my/node/146600. Date of accessed: 2 January 2019.

Ismail, S. Z. (2010). Menangani ajaran sesat di kalangan umat Islam: Perspektif Undang-Undang dan Pentadbiran. Shariah Journal, 18, 2, 247-276.

Jassal, S. T. \& Akcapar, S. K. (2017). Ziyaret and Practical Spirituality: Women's Shrine Visits in Anatolia. Retrieved from: https://www.researchgate.net/publication/321777310_Ch30_Sufi_Shrines_in_Turkey_-_Cambridge_Scholars_Press_UK. Date of accessed: 18 December 2018.

Kendi Dilinden FETÖ: Örgütlü Bir Din İstismarı. (2017). Diyanet İşleri Başkanlığı, Ankara, Retrieved from: https://www.aa.com.tr/uploads/TempUserFiles/haber/2017/07/KENDIDILINDEN-FETO-20170725son.pdf. Date of accessed: 20 December 2018.

Kibaroğlu, M. \& Sazak, S. C. (2015, Winter). Business as Usual: The U.S.-Turkey SecurityPartnership. Middle East Policy, XXII(4), 98-112.

Kurtbag, O. \& Idris, A. (2018). Turkey-Malaysia Foreign Policies on the Threat of Global

Terrorism: ISIS' Emergence and Implications for both Nation-States. In Ebrahimi, Mansoureh \& Yusoff, Kamaruzaman (ed.). The Middle East Arc of Crisis: Political Spin-off and Developmental Outcome, 47-74. Skudai, Johor: UTM Press.

Kutlugun, S. B. (2018, October 09). Indonesian Islamic Scholars Council Declares FETO Haram. The Anatolian Agency, Retrieved from: https://www.aa.com.tr/en/asia-pacific/indonesianislamic-scholars-council-declares-feto-haram/1276341. Date of accessed: 30 December 2018.

Majul, C.A. (1964). Theories on the Introduction and Expansion of Islam in Malaysia. Silliman Journal, xi(4), 335-398.

Malaysiakini, Ashaari Muhammad Dibebaskan, 27 Oktober 2004, Retrieved from: https://www.malaysiakini.com/news/31066._Date of accessed: 30 December 2018.

Malaysiakini, Ashaari Muhammad Meninggal Dunia, 13 Mei 2010, Retrieved from: https://www.malaysiakini.com/news/131721. Date of accessed: 30 December 2018.

Mas'od, M. A. (2013). Diskusi Isu Aqidah dan Pemikiran Semasa di Malaysia. Putrajaya: Jabatan Kemajuan Islam Malaysia.

Miş, N. (2017). Measuring Social Perception of The July 15 Coup Attempt”, In Muhittin Ataman (Ed.), July 15 Coup Attempt in Turkey: Context, Causes and Consequences. Ankara: SETA.

Mustafa, Z., Wan Omar, M., Abu Bakar, A. Y. \& Mohd Nor, A. H. (2013). Fenomena Ajaran Sesat dan Peruntukan Undang-Undang di Malaysia. Selangor: Penerbit UiTM.

Nambiar, P. (2018). Penang Mufti Welcomes Court Ruling in Favour of Ahmadi Muslims, Free Malaysia Today, 7 July, Retrieved from: https://www.freemalaysiatoday.com/category/nation/2018/07/07/penang-muftiwelcomes-court-ruling-in-favour-of-ahmadi-muslims/. Date of accessed: 3 January 2019. 
Ozay, M. \& Saltik, E. (2015). The Myth and Reality of Rukiye Hanim in the Context of Turkish Malay Relations (1864-1904). Insan ve Toplum, 5(9): 55-74.

Özbudun, E. (2011). The Constitutional System of Turkey: 1876 to the Present. New York: Palgrave.

Özkır, Y. (2018, July 15). Batı Medyası ve FETÖ: Stratejik Ortaklıktan Zoraki Beraberliğe. Anadolu Ajansı, Retrieved from: https://www.aa.com.tr/tr/analiz-haber/bati-medyasi-vefeto-stratejik-ortakliktan-zoraki-beraberlige/1204587. Date of accessed: 5 January 2019.

Sallabi, A. M. (2013). Abu Bakr As-Siddeeq: His Life \& Times. Riyadh: International Islamic Publishing House.

Schanzer, J. \& Tahiroglu, M. (2014). Bordering on Terrorism: Turkey's Syria policy and the Rise of the Islamic State, Washington DC: Center on Sanctions and Illicit Finance.

Yayla, A. (2017). July 15: The Glorious Resistance of Turkish Democracy. In Muhittin Ataman (Ed.), July 15 Coup Attempt in Turkey: Context, Causes and Consequences. Ankara: SETA.

Yeşiltaş, M. (2015). Neighboring a Civil War: Turkey's Border Security with Syria. SETA Analysis, No. 17. 